Wawasan:

Jurnal Kediklatan Balai Diklat Keagamaan Jakarta

PISSN: 2548-9232; ${ }_{\mathrm{E}}$ ISSN: 2775-3573

Volume 2 Nomor 1 Tahun 2021: 1-15

\title{
NILAI-NILAI SOSIAL PROFETIK DALAM RITUALITAS IBADAH PUASA RAMADHAN
}

\author{
Athoillah Islamy \\ Institut Agama Islam Negeri Pekalongan, Indonesia \\ e-mail: athoillahislamy@yahoo.co.id
}

\begin{abstract}
Ramadan fasting rituals have a big mission in shaping the social personality of a Muslim. This is because the obligation of fasting is a theocentric-oriented category of worship and an anthropocentric orientation. This study seeks to explore the predictive social values contained in the mandatory religious fasting of Ramadan. This is library research with a philosophical normative approach. Meanwhile, the analytical theory used, namely the theory of social science (ISP), which Kuntowijoyo put forward, was in the form of values of humanization, liberation, and transcendence. The study concludes that three prophetic social values can be taken from the spirituality of Ramadan fasting, including (1) faith commitment as a manifestation of transcendent values, (2) fostering social piety character as a manifestation of liberation, (3) Social care as a manifestation of humanization.
\end{abstract}

Keywords: value; social prophetic; Ramadan fasting

\begin{abstract}
Abstrak
Ritualitas ibadah puasa ramadhan memiliki misi besar dalam pembentukan kepribadian sosial seorang muslim. Hal demikian disebabkan kewajiban ibadah puasa bukanlah sekedar kategori ibadah yang berorientasi teosentris, melainkan juga berorientasi antroposentris. Penelitian ini berupaya untuk mengeksplorasi nilai-nilai sosial profetik yang termuat dalam perintah kewajiban ritualitas ibadah puasa ramadhan. Jenis penelitian ini merupakan penelitian kualitatif berupa kajian pustaka (library research) dengan pendekatan normatif filosofis. Sementara itu, teori analisis yang digunakan, yakni teori Ilmu Sosial Profetik (ISP) yang dicetuskan oleh Kuntowijoyo berupa nilai humanisasi, liberasi dan transendensi. Hasil penelitian menyimpulkan terdapat tiga nilai sosial profetik yang dapat diambil dari ritualitas ibadah puasa ramadhan, antara lain (1) Komitmen keimanan sebagai manifestasi nilai transendensi (2) Pembinaan karakter kesalehan sosial sebagai manifestasi liberasi (3) Kepeduliaan sosial sebagai manifestasi humanisasi.
\end{abstract}

Kata Kunci: nilai; sosial profetik; puasa ramadhan 


\section{PENDAHULUAN}

Tidak dipungkiri di era gobalisasi yang melanda segala aspek kehidupan dewasa ini, kontestasi ideologi dan beragam pemikiran di tengah kehidupan sosial masyarakat modern menjadi hal yang tidak terelakan. Dalam kondisi tersebut, desakan berbagai nilai sosial budaya yang bersumber dari peradaban dunia Barat modern, baik yang berdampak positif maupun negatif dapat mempengaruhi prilaku masyarakat modern

Salah satu dampak negatif dari adanya globalisasi, yakni degradasi moral maupun sosial yang menjadi keprihatinan dan perhatian serius oleh seluruh elemen masyarakat di suatu bangsa dan negara (Ida Bagus Suradarma, 2018: 51).

Merespons problem moral dan sosial sebagaimana di atas, maka keberadaan penguatan kepribadian diri individu yang bermoral melalui basis berbagai nilai dalam ajaran agama merupakan hal niscaya dan sangat dibutuhkan. Dalam konteks inilah, peran pendidikan agama diharapkan dapat mengejawantahkan nilai-nilai spritual sekaligus etika sosial dalam mengikis potensi terjadinya degaradasi moral yang rawan terjadi dalam konteks kehidupan sosial pada masyarakat global (Sofa Muthohar, 2013: 323).

Pada konteks ajaran agama Islam, berbagai nilai pendidikan spritual dan sosial sejatinya dapat ditemukan dalam berbagai bentuk ibadah, terutama pada ritualitas ibadah mahdhah, seperti ritualitas ibadah puasa ramadhan

Penting disadari bahwa sebagai salah satu pilar dalam rukun Islam keberadaan ibadah puasa (puasa ramadhan) bukanlah aktifitas ibadah simbolik tahunan tanpa nilai dan makna melainkan memiliki misi besar dalam pembentukan kepribadian seorang muslim (Mufaizin, 2018: 114124, Ramli Abdul Wahid, 2010: 4-5, Nurjannah, 2014: 37). Hal demikian tidak lain disebabkan kewajiban ibadah puasa bukanlah sekedar kategori ibadah yang berorientasi teosentris, melainkan juga berorientasi antroposentris (Umairso, 2018 :151). Dalam konteks inilah pentingnya kesadaran seorang muslim atas penyahatan nilai-nilai spritual dan sosial yang termuat dalam pelaksanaan ibadah puasa.

Pemaknaan teosentris an sih terhadap perintah kewajiban puasa ramadhan merupakan pemaknaan sempit yang bermuara pada model penalaran teologis yang dikotomis dalam kehidupan keberagamaan. Ciri model penalaran teologis tersebut, yakni terjadinya pemusatan segala aktifitas kehidupan seorang muslim difokuskan pada relasinya terhadap Tuhan, tanpa menghiraukan harkat dan martabat manusia dan problem kemanusiaan dalam kehidupan lingkungan dan sosial sekitar. Dengan kata lain, akan melahirkan wujud keberagamaan yang bersumber dari pemahaman ajaran agama yang tidak utuh sehingga menjadikan ajaran agama hanya memberi janji pahala dan surga dengan mengabaikan dimensi ajaran kemanusiaannya. Oleh sebab itu, ibadah puasa diharapkan dapat menjadi medium bagi seorang muslim dalam mewujudkan relasi manusia dengan Tuhannya, relasi manusia dengan sesama manusia serta relasi lingkungannya berjalan baik. Jika tidak, manifestasi ajaran yang menjadi pesan dalam ibadah puasa akan 
pincang dan distorsif (Cholil Nafis, 2015:140). Muhammad Mutawalli AsSya'rowi sebagaimana yang dikutip oleh Sansan Ziaul Haq menuturkan bahwa esensi ibadah puasa bertujuan agar seorang muslim dapat beristiqomah menghidupkan nilai-nilai puasa tidak hanya selama bulan suci Ramadhan, melainkan tetap berlanjut setelah berakhirnya bulan suci Ramadhan (Haq, 2016: 199).

Berdasarkan uraian latar belakang yang telah penulis uraikan sebelumnya, maka dirumuskan sebuah pertanyaan penelitian, yakni “Apa saja nilai-nilai sosial profetik yang termuat dalam ritualitas ibadah puasa ramadhan?" Sementara itu, tujuan dari penelitian ini, yakni untuk melakukan analisis eksploratif terkait nilai-nilai sosial profetik yang termuat dalam ritualitas ibadah puasa ramadhan.

\section{METODE}

Jenis penelitian ini masuk kategori penelitian kualitatif yang berupa kajian pustaka (library research). Sumber data utama penelitian ini, yakni buku Menyingkap Tabir Puasa Ramadhan karya Cholil Nafis (2015). Sementara itu, sumber data sekunder penelitian yang digunakan, yakni berbagai literatur ilmiah yang relevan dengan fokus objek pembahasan penelitian ini. Pendekatan penelitian yang digunakan dalam penelitian ini berupa pendekatan normatif filosofis dengan menggunakan teori analisis, yakni teori Ilmu Sosial Profetik (ISP) yang dicetuskan oleh Kuntowijoyo berupa nilai humanisasi, liberasi dan transendensi. Adapun sifat pendekatan penelitian ini, yakni deskriptif-analitik. Namun tidak hanya bersifat deskriptif- analitik, melainkan juga bersifat preskriptif dalam memberikan saran yang berpijak dari analisis pembahasan.

\section{HASIL DAN PEMBAHASAN Hasil Penelitian Mengenai Puasa}

Penulis menyadari bahwa kajian atau penelitian ilmiah terkait nilai-nilai fislosofis yang termuat dalam ritualitas ibadah puasa telah cukup banyak diuraikan oleh beberapa penelitian sebelumnya. Oleh karena itu, dalam sub bab literature review ini, akan penulis uraikan beberapa penelitian sebelumnya yang memiliki relevansi dengan objek inti pembahasan dalam penelitian ini. Hal demikian dimaksudkan agar dapat menunjukan distingsi penelitian ini dari berbagai penelitian sebelumnya. Penjelasan lebih sebagai berikut.

Diawali oleh penelitian Julianto dan Muhopilah (2015) dengan Judul "Hubungan Puasa dengan Tingkat Regulasi Kemarahan," Penenlitian tersebut menyimpulkan terdapat relasi antara pelaksanaan ibadah puasa dengan tingkat regulasi kemarahan individu yang melaksanakannya. Di mana individu yang sering menjalankan puasa, maka pasokan karbohidrat dalam tubuhnya lebih rendah, sehingga memiliki potensi tingkat kemarahan yang tinggi (Julianto dan Muhopilah. 2015:3). Penelitian Julianto dan Muhopilah ini lebih menekankan pada aspek hubungan ibadah puasa secara medis dengan kondisi emosional kejiawaan dalam diri seorang yang berpuasa.

Kemudian penelitian Umiarso dan Makhful (2018) dengan judul "Puasa dan Pendidikan Agama Islam dalam Membangun Manusia Penaka 
"Tuhan": Tinjauan Kritis Terhadap Sisi Epistemologik dan Aksiologik (Pembelajaran) Pendidikan Agama Islam," Pada penelitian tersebut dinyatakan bahwa eksistensi ibadah puasa dapat menjadi medium dalam membentuk jati diri manusia yang memiliki potensi kemanusiaan dan ketuhanan. Hal demikianyang kemudian menjadi basis paradigmatic model pembelajaran humanis yang meletakkan subjek dan objek pendidikan agama Islam menjadi manusia pembelajar (Umiarso dan Makhful,2018: 129). Penelitian Umiarso dan Makhful ini lebih mengfokuskan pada aspek epsitemologi dan aksiologi terkait korelasi antara ritualitas ibadah puasa dengan pembelajaran materi Pendidikan Agama Islam (PAI).

Berikutnya, bertolak belakang dari hasil penelitian Very dan Pipih sebagaimana yang telah diuraikan di atas, penelitian Pipih Muhopilah, Witrin Gamayanti dan Elisa Kurniadewi (2018) dengan judul "Hubungan Kualitas Puasa dan Kebahagiaan Santri Pondok Pesantren AlIhsan," justru menunjukan bahwa terdapat relasi kualitas ibadah puasa dengan kebahagiaan seorang yang menjalankannya. Di mana pada saat berpuasa seorang individu termotivasi untuk selalu bersikap sabar, berperilaku baik yang kemudian sikap tersebut berimplikasi pada emosi positif dan kepuasan. Kondisi demikianlah yang kemudian dapat meningkatkan kualitas puasa dan juga rasa kebahagiaan yang dialaminya. Pipih Muhopilah, Witrin Gamayanti, Elisa Kurniadewi, 2018: 53).

Selanjutnya, Mufaizin dengan judul "Kearifan Syariat dan Hikmah dalam Puasa," Penelitian tersebut menyatakan bahwa studi terkait hikmah dibalik pensyariatan ibadah puasa akan senantiasa dinamis seiring kondisi Ilmu Pengetahuan yang berkembang. Kondisi demikian yang kemudian dapat berimplikasi pada fakta-fakta baru yang dapat menjadi anugerah bagi kehidupan umat Islam (Mufaizin,2018:125).Penelitian

Mufaizin ini menekankan pada penggalian nilai-nilai hikmah ibadah puasa dengan perkembangan ilmu pengetahuan.

Safria Andy (2018) dengan judul "Hakikat Puasa Ramadhan dalam Perspektif Tasawuf (Tafsir Q.S Al-Baqarah: 183)." Penelitian tersebut menunjukan bahwa ritualitas ibadah puasa mengandung berbagai nilai dalam kehidupan tasawuf, antara lain sikap kejujuran, pengakuan kepemilikian Allah Swt atas alam semesta, kesadaran atas kelemahan seorang hamba yang senantiasa membutuhkan pertolongan Allah Swt, dan rasa hina seorang hamba yang senantiasa dapat memperbaiki prilakunya (Safria Andy, 2018:16). Penelitian yang dilakukan Safria ini cenderung menggunakan perspektif tasawuf dalam menggali nilai-nilai hikmah yang termuat dalam ritualitas ibadah puasa.

Berpijak dari berbagai penelitian terdahulu yang telah dipaparkan di atas, dapat disimpulkan bahwa berbagai penelitian terdahulu tersebut memiliki sisi distingsi perspektif sekaligus temuan masing-masing. Ada yang menggunakan perspektif tasawuf, medis, psikologi, bahkan sains.

Berbeda dengan berbagai penelitian di atas yang memiliki kecenderungan perspektif secara parsial, penelitian ini berupaya menggali berbagai nilai falsafah yang termuat dalam ritualitas ibadah puasa 
melalui paradigma nilai Ilmu Sosial Profetik yang dietuskan Kuntowijoyo meliputi nilai humanisasi, liberasi dan transendensi. Melalui paradigma tersebut, penelitian ini diharapakan dapat mengeksplorasi sekaligus mengidentifikasi berbagai nilai sosial profetik dalam aktifitas ibadah puasa.

\section{Paradigma Ilmu Sosial Profetik (ISP)}

Ketika terjadi polemik perdebatan antara berbagai ilmu sosial Barat sekuler dan ilmu sosial Islam, muncullah sosok intelektual muslim Indonesia yang bernama Kuntowijoyo (Putri Wulansari dan Nurul Khotimah, 2019: 224). Ia hadir dengan menawarkan ide orisinal dan kritis sebagai pengembangan paradigma ilmu sosial yang disebutnya dengan istilah Ilmu Sosial Profetik (ISP). Ide ISP merupakan upaya saintifikasi (pengilmuan) ajaran Islam yang bersumber dari landasan teologis Islam, baik al-Quran maupun Hadis (Athoillah Islamy,2020 :177) Melalui ide ISP yang dicetuskannya tersebut, Kuntowijoyo membangun jalan penghubung antara ilmu sosial sekuler dengan gerakan Islamisasi ilmu sosial (Perdana Boy ZTF, 2011: 95-96).

Sebagaimana yang telah disinggung di atas, bahwa Ide Ilmu Sosial Profetik (ISP) memiliki tujuan untuk menjadikan ilmu sosial memiliki landasan nilai teologis dalam hal orientasi yang akan dicapainya. Oleh sebab itu, ide ISP bukan hanya untuk memahami realitas secara apa adanya, melainkan lebih dari itu, yakni mentransformasikan berbagai cita atau nilai luhur yang didambakan dalam kehidupan sosial kolektif. Atas dasar inilah, dirumuskan tiga nilai landasan paradigmatik dalam ide ISP, yakni nilai humanisasi (amar makruf), liberasi (nahi munkar) dan transendensi (keimanan) yang diderivasikan dari misi ajaran Islam dalam Qs. Ali Imran, ayat 110 (Husnul Muttaqin, 2015: 221-222). Ketiga landasan nilai tersebut bukan hal yang bersifat dikotomis melainkan integratif dalam membumikan nilainilai ajaran Islam dalam konteks kehidupan social (Maskur, 2012: 127). Adapun uraian penjelasan lebih lanjut tentang tiga landasan nilai dalam ide ISP, sebagai berikut.

\section{Humanisasi}

Humanisasi menjadi landasan nilai yang berpijak pada pemaknaan ajaran Islam berupa amar ma'ruf (Husnul Muttaqin, 2015:225). Dalam ide Ilmu Sosial Profetik (ISP), manifestasi nilai humanisasi berorientasi untuk memanusiakan manusia dengan cara menghilangkan kebendaan, ketergantungan, kekerasan dan kebencian dari manusia (Muhammad Zainal Abidin, 2016: 155). Dalam konteks inilah, pada dasarnya humanisasi memiliki titik temu dengan gerakan liberalisme Barat. Namun demikian, terdapat distingsi mendasar, yakni jika peradaban Barat berpijak pada humanisme antroposentris yang menila eksistensi kehidupan manusia dibangun oleh diri manusia sendiri tanpa intervensi kekuasaan Tuhan (Husnul Muttaqin,2015:225-226). Sedangkan ide humanisme ISP berpijak pada nilai humanisme teosentris yang tidak dapat dilepaskan dari dimensi transendensi yang menjadi landasan epistemologinya (Isfaroh, 2019: 211).

Melalui humanisme teosentris, Kuntowijoyo ingin menyadarkan manusia kembali untuk memusatkan berbagai aktiftasnya kepada Tuhan, 
dengan tetap borientasi pada kemaslahatan hidup manusia (Husnul Muttaqin, 2015:225-226). Paradigma demikian, meniscayakan dua macam sumber pengetahuan dan kebenaran yang ditekankan dalam nilai humanisme ISP, yakni bersumber dari Tuhan dan dari manusia (Muhammad Zainal Abidin, 2016: 145). Dengan demikian dapat disimpulkan bahwa humanisasi dalam yang dicetuskan oleh Kuntowijoyo lebih tepat disebut humanisasi teo-antroposentris, karena memiliki landasan nilai transendensi yang bersumber dari ajaran Islam, dan landasan nilai kemanusiaan yang bersumber dari akal sehat manusia.

\section{Liberate}

Liberasi merupakan pemaknaan dari nilai ajaran Islam berupa nahi munkar (Husnul Muttaqin, 2015:226). Abdul Karim Syeikh menuturkan bahwa term munkar tidak terbatas ditujukan pada hal yang dingkari dan dilarang agama, melainkan juga dtujukan pada berbagai hal yang tidak dapat diterima oleh logika sehat, budaya dan adat dalam kehidupan manusia (Abdul Karim Syeikh, 2018 :19). Dalam paradigma Ilmu Sosial Profetik (ISP), nilai liberasi yang memiliki tanggung jawab yang berpijak pada ajaran Islam dalam membebaskan kehidupan manusia dari berbagai tindakan yang kontra produktif atau bertentangan dengan nilai-nilai kemanusiaan itu sendiri, seperti dominasi struktur yang menindas, diksriminasi, hegemoni, tirani, dan lain sebagainya (Husnul Muttaqin, 2015: 226).

Penting diketahui bahwa dalam nilai liberasi ISP ini, terdapat empat objek utama yang menjadi target orientasi. Pertama, liberasi sistem pengetahuan yang bertujuan untuk membebaskan manusia orang dari sistem pengetahuan materialistis, dan dari dominasi struktur kelas, dan seks. Kedua, liberasi dalam sistem social yang berorientasi untuk menjaga manusia dari dampak negartif sistem sosial industrial. Ketiga, liberasi dari sistem ekonomi yang berdampak buruk berupa kesenjangan kesejahteraan dalam kehidupan antar umat manusia. Keempat, liberasi dalam sistem politik yang bermaksud untuk membebaskan sistem politik yang otoriter, diktator, neofeodalisme dan lain sebagainya (Muhammad Zainal Abidin, 2016: 157). Dari sini dapat dipahami bahwa nilai liberasi dalam ide ISP tidak terbatas pada penjelasan eksplisit dalam landasan teologis normatf, melainkan juga dapat berdasarkan norma sosiologis maupun antropologis.

\section{Transcendence}

Transendensi menjadi landasan nilai berpijak dari ajaran Islam yang berupa perintah untuk menjaga komitmen keimanan. Dalam konteks nilai transendensi ini, berbagai nilai yang menajdi dasar keimanan dalam ajaran Islam menjadi bagian inti dalam mewujudkan sebuah peradaban umat manusia. Dengan kata lain, nilai transendensi menempatkan nilai-nilai posisi sangat sentral dalam ide Ilmu Sosial Profetik (ISP) (Husnul Muttaqin, 2015:227-228). Menurut Muhammad Zaenal Abdin, transendensi merupakan bentuk kesadaran orientasi kerja manusia sebagai bentuk beribadah (Muhammad Zainal Abidin, 2016: 158).

Penting diketahui bahwa dalam ide ISP, nilai transendensi memiliki 
peran yang sangat urgen dalam membimbing tujuan hidup seorang muslim sebagai manusia. Pada konteks inilah, nilai transendensi dapat memberikan arah untuk apa berbagai tindakan humanisasi dan liberasi dilakukan (Husnul Muttaqin, 2015:228). Dalam konteks ini, jika dilihat dalam perpektif psikologi Islam, maka Islam merupakan ajaran agama yang memuat sumber nilai yang dapat dijadikan sebagai pedoman hidup dalam pembentukan psikis dan perilaku manusia yang baik (Athoillah Islamy, 2019 :38). Oleh karena itu, humanisasi, liberasi, dan transendensi dalam ide ISP merupakan tiga nilai yang berjalan integratif bukan dikotomis (Maskur, 2012: 127). Dengan demikian dapat disimpulkan bahwa tiga landasan nilai (humanisasi, liberasi, dan transendensi) dalm ide Ilmu Sosial Profetik (ISP) yang dicetuskan Kuntowijoyo merupakan trilogi nilai sosial profetik yang bekerja sama dalam pembentukan kepribadian manusia dalam kehidupan sosial.

\section{Tiga Nilai Sosial Profetik Puasa Ramadhan}

Selain memiliki karakter daya kritis pada realitas kehidupan sosial umat manusia, ajaran Islam juga memilki fungsi transformatif dalam rangka mentransmisikan berbagai nilai ajaran dalam kehidupan sosial masyarakat. Fungsi transformatif ajaran Islam ini kemudian menunjukan bahwa esensi dari ajaran Islam tidaklah sebatas pada orientasi pembentukan akhlak dalam kehidupan individu pemeluknya semata, melainkan juga akhlak sosial (Athoillah Islamy, 2021: 61).
Berpijak pada penjelasan di atas, maka keberadaan pensyariatan kewajiban ibadah Puasa Ramadhan dan hari raya idul fitri merupakan dua momen yang tidak dapat dipisahkan. Keduanya memiliki relasi keterkaitan sekaligus keberlanjutan dalam menanamkan misi ajaran Islam yang mulia bagi pembentukan kepribadian umat Islam. Oleh karena itu, untuk memahami apa makna yang termuat dalam perayaan hari raya Idul Fitri, maka penting perenungan reflektif atas perjalanan Ibadah Puasa yang telah seorang muslim lewati selama bulan suci Ramadhan. Dalam hal ini, setidaknya ada dua pertanyaan refleksi sebagai berikut. Bagaimana kita menjalani hari-hari dalam berpuasa Ramdhan ? Hikmah dan manfaat apa saja yang sudah kita dapatkan dari berpuasa Ramadhan?

Idul Fitri merupakan hari kembalinya manusia pada fitrah kesuciannya. Suci dari segala khilaf, salah dan dosa setelah menempuh Ibadah Puasa selama bulan suci Ramadhan sebagaimana yang telah dijelaskan dalam Hadis Nabi yang berbunyi:

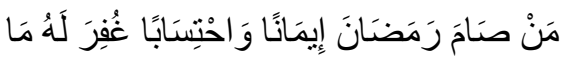

$$
\begin{aligned}
& \text { تَقَََََ مِنْ ذَنْبهِ }
\end{aligned}
$$

Artinya "Barangsiapa yang berpuasa Ramadhan karena iman dan ikhlas berharap pahala dari Allah SWT, maka akan diampuni dosa-dosanya yang telah lalu."(HR.Al-Bukhari dan Muslim)

Namun demikian tidak dipungkiri manusia tidak selamanya dapat menjaga fitrah kesuciannya. Tidak jarang bahkan seringkali fitrah kesucian tersebut ternodai oleh hiruk pikuk pergaulan, ambisi hidup dan 
dosa yang dilakukan manusia dalam menjalani kehidupannya sehari-hari. Pada kondisi inilah, manusia sering lupa akan fitrahnya, lupa akan asal mulanya sebagai hamba yang memiliki fitrah salimah, yakni fitrah dalam kondisi suci yang belum terpolusi, sehingga senantiasa membawa dirinya pada kehidupan yang baik, tenang dan damai. Dalam hal ini, Al-Qurtubi sebagaimana yang dikutip Saryono menjelaskan bahwa fitrah bermakna kesucian jiwa dan rohani yang melekat kepada pribadi manusia sejak lahir dalam keadaan suci dalam arti tidak memiliki dosa. Terkait konsep fitrah ini, Al-Maraghi juga menuturkan bahwa fitrah mengandung maksud arti kecenderungan untuk mencari dan menerima kebenaran (Saryono, 2016: 164-165).

Dalam rangka menjaga fitrah kesucian dalam diri seorang muslim pasca berakhirnya bulan suci Ramadhan, maka penting kiranya menghidupakan kembali nilai-nilai mulia yang termuat dalam ritualitas puasa ramadhan pada kehidupan sehari-hari. Dalam sub bab pembahasan inti ini, penulis akan menguraikan setidaknya terdapat tiga nilai sosial profetik dalam ritualitas puasa ramadhan yang dapat senantiasa kita hidupkan kembali dalam kehidupan sehari-hari, antara lain sebagai berikut.

\section{Komitmen Keimanan Sebagai Manifestasi Nilai Transendensi}

Dalam perspektif teologi Islam, dijelaskan bahwa konstruksi sebuah bangunan keimanan seorang muslim meliputi dimensi batiniah dan dimensi lahiriah. Di mana dimensi esoteris merupakan dimensi sikap kepercayaan atau keyakinan sepenuh hati pada berbagai doktrin ajaran Islam. Sedangkan dimensi eksoteris merupakan tindakan empiris, baik berupa ucapan lisan dan lain sebagainya sebagai manifestasi kondisi batiniahnya (Shodiq, 2104: 132).

Penting disadari kembali bahwa ibadah puasa merupakan medium bagi seorang muslim untuk dapat melatih, mengasah sekaligus meningkatkan kualitas ketaatannya dalam beragama (Taufik Mukmin, 2017: 42).

Salah satu ciri yang melekat kuat terkait aspek ketaatan dalam ibadah puasa yakni sikap keimanan. Wujud konkrit keimanan ini tercermin dalam pelaksanaan ibadah puasa yang disertai keyakinan bahwa segala aktifitas dalam berpuasa senantiasa diawasi oleh Allah Swt. Padahal sejatinya orang yang sedang berpuasa sangatlah mudah melakukan kebohongan publik, yakni dengan berpura-pura untuk tidak makan dan tidak minum di depan orang lain. Namun dengan adanya keyakinan terhadap pengawasan Allah Swt dalam setiap tindakannya, maka ia tetap konsisten menjaga puasanya (Cholil Nafis, 2015: 79). Berbeda dengan berbagai ibadah lainnya yang mudah diidentifikasi oleh panca indera manusia karena adanya gerakangerakan simbolik, seperti shalat, zakat, haji (Sansan Ziaul Haq, 2016: 193). Oleh sebab itu, tidaklah mengherankan jika Kondisi tersebutlah yang kemudian tidak berlebihan jika puasa dipandang sebagai kategori ibadah yang sangat privasi.

Dalam ide Ilmu Sosial Prefetik (ISP), komitmen keimanan yang melekat pada pelaksanaan ibadah puasa juga dapat disebut sebagai 
wujud komitmen transendensi seorang muslim dalam ber-Islam. Dalam konteks inilah, sikap ihsan juga penting dibutuhkan guna memperkokoh sikap transendensi seorang muslim dalam kehidupan beragama. Sebagaimana penting kita ketahui kembali secara definitif, term Ihsan telah dijelaskan oleh Nabi Muhammad SAW dalam Hadisnya yang artinya: Ihsan adalah ketika kamu beribadah kepada Allah seolaholah kamu melihat-Nya, dan jika kamu tidak dapat melihatnya, maka Allah pasti melihatmu'." (HR Muslim). Dalam perspktif tasawuf, sikap ihsan dipandang sebagai bentuk penghayatan intensif dan mendalam atas kehadiran Tuhan dalam diri kehidupan sehari-hari seorang muslim (Justin Parrot, 2009: 20). Zaman Nazim Ali menyebut ihsan menempati level tertinggi dalam trilogi sikap keberagamaan Islam, yakni Islam, iman dan ihsan (Zaman Nazim Ali, 2012:120121). Oleh karenanya, tidaklah berlebihan Justin Parrot menyebut Ihsan dipandang sebagai puncak pendakian tertinggi dalam kehidupan keberagamaan umat Islam (Justin Parrot, 2009: 20).

Sebagaimana kita ketahui kembali bahwa dalam ide Ilmu Sosial Profetik, nilai transendensi berpijak dari ajaran Islam yang berupa komitmen keimanan. Di mana berbagai landasan nilai keimanan dalam ajaran Islam merupakan hal yang urgen untuk mewujudkan kepribadian dalam kehidupan seorang muslim(Husnul Muttaqin, 2015:227-228). Manifestasi dari komitmen keimanan sebagai nilai transendensi tersebut dalam ritualitas ibadah puasa tidak dapat dilepaskan dari ajaran agama yang berkaitan erat dengan sikap keimanan, seperti sikap Islam dan ihsan.

Relasi antara iman, Islam, dan ihsan merupakan trilogi ajaran Islam yang tidak dapat dikotomikan dalam ritualitas ibadah puasa dan berbagai ritualitas ibadah yang lain (selain puasa). Dalam ranah praksisnya, satu dengan lainnya merupakan satu keutuhan yang saling berkaitan. Iman berkaiatan aspek keyakinan (kepercayaan) dalam hati seorang muslim. Sementara, Islam memiliki makna keselamatan, kepatuhan, dan ketundukan seorang muslim terhadap ajaran Islam. Sedangkan ihsan berarti sikap selalu berbuat baik karena merasa adanya pengawasan dan kehadiran Tuhan dalam kehidupan seorang muslim (Nur Hadi, 2019: 5). Dengan demikian dapat dikatakan bahwa sebagai ibadah jasmani dan sekaligus nafsani, ibadah puasa dapat menjadi medium untuk menanamkan dan mengasah nilai transendensi dalam ajaran Islam yang berupa Islam, Iman dan Ihsan, sehingga diharapkan hati seorang muslim dapat mengalami ketentraman dalam mengarungi kehidupan sehari-hari.

\section{Pembinaan Karakter Kesalehan Sosial Sebagai Manifestasi Nilai Liberasi}

Upaya dalam pembentukan kepribadian atau karakter individu dapat melalui pengoptimalisasian pembelajaran sekaligus penanaman berbagai nilai sosial dan agama. Hal ini disebabkan pendidikan karakter atau kepribadian memiliki korelasi erat dengan nilai-nilai spritualitas yang bersumber dari ajaran agama (Athoillah Islamy, Dwi Puji Lestari, Saihu, Nurul Istiani, 2020: 175). 
Penting disadari proses pendidikan karakter dapat dipahami sebagai bentuk pendidikan nilai, budi pekerti, moral, bahkan pendidikan watak. Oleh sebab itu, orientasi dari proses pendidikan karakter yakni untuk melakukan transmisi kecerdasan berfikir, penghayatan, bersikap, dan perilaku yang baik (Nurul Istiani, Athoillah Islamy, 2020:41-42).Dalam konteks inilah, jika dilihat dalam kacamata psikologi Islam, bahwa Islam sebagai ajaran agama telah memuat sumber nilai pedoman hidup seorang muslim dalam membentuk psikis dan perilaku seorang muslim yang baik (Athoillah Islamy, 2019: 38).

Terkait nilai-nilai pembentukan prilaku atau karakter kepribadian sosial seorang muslim sejatinya dapat dengan mudah kita temukan dalam ritualitas ibadah puasa. Atas dasar inilah, maka penting disadari kembali bahwa pemahaman tentang berbagai ritualitas ibadah mahdhoh, tidaklah cukup berhenti pada aspek legal formal fikih semata, seperti syarat, rukun, dan hal-hal yang membatalkannya, melainkan penting memahami berbagai makna yang terkandung dalam pelaksanaan ibadah tersebut(Athoillah Islamy, 2020: 108109). Hal demikian tidak terkecuali dalam memahami makna di balik perintah kewajiban ibadah puasa ramadhan. Sebagaimana penting diketahui dan disadari kembali bahwa kata imsak (menahan) sebagai kata kunci dalam ibadah puasa tidaklah sekedar berupa aktifitas simbolik menahan perkara-perkara yang dilarang, seperti makan, minum, berhubungan intim di siang hari. Namun juga harus dipahami sebagai aktifitas menahan keinginan hawa nafsu. Hal demikian tidaklah lain disebabkan ibadah puasa bukanlah sekedar ibadah yang menekankan aktifitas jasmani, melainkan juga aktiftas nafsani (Athoillah Islamy, 2021: 126). Dalam konteks puasa nafsani, ibadah puasa dapat menjadi sarana pembetukan karakter seorang muslim. Melailui ibadah puasa dharapakan akan melahirkan pribadi-pribadi muslim yang memiliki prinsip tangguh, kesabaran, dan keiklasan sebagaimana dijelaskan dalam Hadis Nabi yang berbunyi:

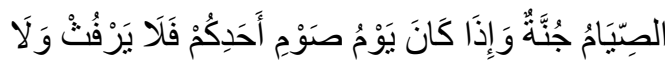

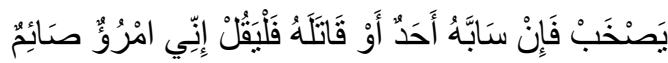

Artinya "Puasa merupakan perisai, jika salah seorang dari kalian sedang berpuasa janganlah berkata keji dan berteriak-teriak, jika ada orang yang mencercanya atau memeranginya, maka ucapkanlah, 'Aku sedang berpuasa" (H.R. Bukhari dan Muslim).

Hadis di atas mengisayaratkan bahwa puasa bagaikan perisai atau tameng yang dapat menjaga pertahanan dari serangan musuh. Berpijak pada penjelasan normatif Hadis tersebut dapat kita pahami pada dasarnya seseorang yang sedang berpuasa, sejatinya ia sedang melakukan penguatan diri dari serangan hawa nafsu yang selalu menjerumuskan pada perbuatan tercela. Tidak sekedar itu, perintah untuk menyatakan diri sebagai orang yang sedang berpuasa ketika ada yang menghina atau memeranginya menunjukan pesan ajaran Islam agar kita bersikap pasif dalam berbagai tindakan yang dapat memicu disintegrasi sosial, seperti permusuhan, pertikaian, peperangan dan lain 
sebagainya. Dalam konteks inilah pesan moral atau makna sosial yang termuat dalam aktifitas ritualitas ibadah puasa dapat dikatakan paralel dengan nilai liberasi. Di mana dalam ide Ilmu Sosial Profetik (ISP), nilai liberasi (nahi munkar) diposisikan pada konteks ilmu atau nilai sosial yang memiliki tanggung jawab profetik dalam menghindarkan kehidupan manusia dari berbagai tindakan yang bertentangan atau kontra produktif dengan semangat nilai kemanusiaan itu sendiri, seperti kekejaman, dominasi struktur yang menindas, diksriminasi, hegemoni, tirani, dan lain sebagainya (Husnul Muttaqin, 2015: 226).

Nilai liberasi dalam ritualitas ibadah puasa merupakan nilai yang membutuhkan perenungan dan kesadaran mendalam bagi pelakunya untuk mewujudkannya sebagai nilai kongkrit dalam kepribadian dan tingkah laku. Dalam konteks inilah penting kita merujuk pada nasihat Hujjatul Islam Abu Hamid Muhammad bin Muhammad Al-Ghazali Al-Thusi Al-Shafi'i $(450 \mathrm{H}-505 \mathrm{H})$ atau yang sering kita kenal dengan nama Imam Al-Ghazali. Menurut al-Ghazali setidaknya ada enam adab yang harus dijaga dalam menjalankan ibadah puasa, antara lain. Mengkonsumsi makanan-makanan yang halal \& baik Menghindari perselisihanMenjauhi ghibah Tidak berbohong, Tidak menyakiti orang lain, Menjaga anggota badan dari segala perbuatan buruk.

Keenam adab berpuasa sebagaimana nasihat Al-Ghazali di atas dapat menjadi element penting dalam pembinaan karakter nilai liberasi dalam diri seorang muslim selama menjalankan ibadah puasa dan dapat kita teruskan pada kehidupan seharhari setelah berakhirnya bulan suci ramadhan, terlebih dalam kondisi problem karakter dan sosial yang melanda Bangsa Indonesia saat ini, seperti merajalelanya fenomena kriminalisasi, konflik sosial, intoleransi, praktek korupsi yang semakin massif (Athoillah Islamy, 2020: 156), bahkan aksi kekerasan maupun terorisme atas nama agama.

\section{Kepedulian Sosial Sebagai Manifestasi Nilai Humanisasi}

Melalui ibadah puasa, seorang muslim dapat memahami pesan ajaran Islam terkait pentingnya menjaga hubungan baik antara manusia dengan Tuhannya (hablun minnallah) sekaligus hubungan baik antara manusia dengan sesama manusia (hablun minannas). (Umairso, 2018 :151). Dalam ibadah puasa, umat Islam dilatih untuk berempati pada kondisi orang lain dan lingkungan sekitarnya. Sikap empati tersebut bukanlah karena sama-sama dalam kondisi lapar dan haus semata, melainkan tentang bagaimana kita dapat menumbuhkan sikap kepedulian sosial. Selaras dengan nilai kepeduliaan sosial ini, Nabi Muhammad Saw menyebut bulan Ramadhan sebagai Syahr al-Muwâsat, yang berarti "Bulan Kepekaan Sosial". (HR. Ibn Khuzaimah). Predikat sebagai bulan kepekaan sosial juga dikuatkan dalam Hadis Nabi terkait anjuran untuk memberi makan orang yang berbuka puasa.

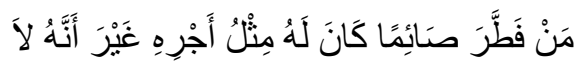

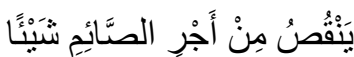

Artinya: "Barangsiapa memberi makan orang yang berpuasa, maka baginya pahala seperti orang yang berpuasa 
tersebut, tanpa mengurangi pahala orang yang berpuasa itu sedikitpun." (HR. Tirmidzi no. 807, Ibnu Majah no. 1746, dan Ahmad 5: 192. Al-Hafizh Abu Thahir mengatakan bahwa hadits ini shahih) (Cholil Nafis, 2015: 142).

Tidak hanya anjuran memberi makan berbuka, dalam Hadis lain juga menunjukan adanya nilai kepedulian sosial dalam bentuk perintah mengeluarkan zakat fitrah sebagaimana Hadis Nabi yang berbunyi:

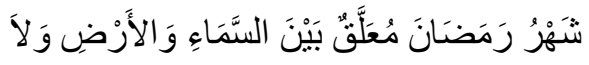

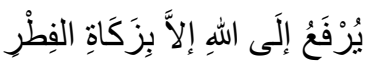

Artinya :"Pahala puasa Ramadhan digantungkan antara langit dan bumi, tidak diangkat kepada Allah kecuali dengan dibayarkannya zakat fitrah. ${ }^{1}$

Berpijak pada pesan kepedulian sosial dalam dua Hadis di atas, menunjukan bahwa ibadah puasa tidak dapat dilepaskan dari fungsi kepedulian sosial yang mengikutinya. Fungsi tersebut tidak lain agar melalui ibadah puasa, seorang muslim dapat membiasakan diri berperan aktif dalam mewujudkan format kehidupan sosial kolektif yang adil, harmonis dan juga sejahtera.

Keberadaan pesan kepeduliaan sosial yang termuat dalam ritualitas ibadah puasa dapat dikatakan sebagai nilai humanisasi. Sebagaimana penting diketahui kembali bahwa nilai humanisasi dalam paradigma Ilmu Sosial Profetik (ISP) merupakan nilai profetik yang timbul dari pemaknaan kreatif terhadap ajaran Islam yang berupa amar ma'ruf (menegakkan kebenaran) Dimana istilah amar ma"ruf memiliki makna atau maksud yang beragam, antara lain makna keutamaan, kebenaran, keadilan, kelayakan, pantas, patut dan bakti (Abdul Karim Syeikh, 2018 :19). Oleh sebab itu, pesan kepeduliaan sosial dalam ritualitas ibadah puasa dapat dikatakan sebagai bagian dari manifestasi nilai humanisasi dalam arti makna yang lebih luas. Kesimpulan demikian tidaklah berlebihan mengingat dalam paradigma ISP, manifestasi nilai humanisasi sejatinya bertujuan untuk memanusiakan manusia, menghilangkan kebendaan, ketergantungan, kekerasan dan kebencian dari manusia (Muhammad Zainal Abidin, 2016: 155).

Syeikh Yusuf Al-Qardhawi sebagaimana yang dikutip oleh Cholil Nafis menuturkan bahwa semangat kerekatan sosial dalam diri seorang muslim yang berpuasa merupakan bentuk implikasi sosial dari ritualitas ibadah puasa yang tumbuh dari kondisi yang sama dalam merasakan penderitaan dan kepedihan atas kurangnya kesejahteraan ekonomi yang dialami oleh orang-orang fakir dan miskin, seperti halnya rasa kekurangan dan kelaparan (Cholil Nafis, 2015:77). Oleh karena itu, wujud kongkrit kepedulian sosial yang mengiringi pelaksanaan ibadah puasa, baik dalam bentuk pemberian sedekah atau pembayaran wajib zakat fitrah dapat menjadi medium dalam mewujudkan tujuan dari nilai humanisasi yang berupa sikap sosial kemanusiaan dan menghilangkan jurang kesenjangan kesejahteraan sosial antara orang yang memiliki kondisi finansial yang baik dengan orang yang mengalami kekurangan, bahkan kesusahan dalam kehidupan finansialnya. 


\section{KESIMPULAN}

Berpijak pada uraian pembahasan di atas dapat disimpulkan bahwa ritualitas ibadah puasa ramadhan sejatinya memuat berbagai nilai ajaran sosial profetik bagi kehidupan umat Islam antara lain berupa (1) Komitmen keimanan sebagai manifestasi nilai transendensi (2) Pembinaan karakter kesalehan sosial sebagai manifestasi liberasi (3) Kepeduliaan sosial sebagai manifestasi humanisasi.
Setidaknya manifestasi tiga nilai sosial profetik dalam ritualitas ibadah puasa di atas dapat menjadi medium seorang muslim untk dapat senantiasa berevolusi diri menjadi pribadi-pribadi yang lebih baik, sehingga apa yang digambarkan tentang kembalinya manusia ke fitrah kesuciannya di hari raya Idul Fitri dapat terwujud melalui gambaran perilaku dalam kehidupan sehari-hari setelah berakhirnya Bulan Suci Ramadhan.

\section{DAFTAR PUSTAKA}

Abidin, Muhammad Zainal. (2016). Paradigma Islam dalam Membangun Paradigma Ilmu Integralistik: Membaca Kuntowijoyo, Banjarmasin: IAIN Antasari Press.

Andy, Safria. (2018). Hakikat Puasa Ramadhan dalam Perspektif Tasawuf (Tafsir Q.S Al-Baqarah: 183). Ibn Abbaas : Jurnal Ilmu Alqur'an dan Tafsir, 1(1).

Hadi, Nur. (2019). Islam, Iman Dan Ihsan Dalam Kitab Matan Arba'In An-Nawawi: Studi Materi Pembelajaran Pendidikan Islam dalam Perspektif Hadis Nabi SAW. Jurnal Intelektual: Jurnal Pendidikan dan Studi Keislaman, 9(1).

Haq, Sansan Ziaul. (2016). Dimensi Eksoterisme dalam Tafsir Ishari. Tesis, Sekolah Pascasarjana Universitas Islam Negeri Syarif Hidayatullah Jakarta.

Isfaroh.(2019). Humanisme Teosentris: Telaah Sosiologi Pengetahuan Pemikiran Kuntowijoyo. Panangkaran, Jurnal Penelitian Agama dan Masyarakat, 3(2).

Islamy, Athoillah (2020). Haji Mabrur dalam Paradigma Fikih Sosial Sufistik. Jurnal AlQalam: Jurnal Penelitian Agama dan Sosial Budaya, 26(1).

Islamy, Athoillah, Dwi Puji Lestari, Saihu, Nurul Istiani. (2020). Pembiasaan Ritualitas Kolektif dalam Pembentukan Sikap Sosial Religius Anak Usia Dini (Studi Kasus di TK Islam Az Zahra, Kebayoran Baru, Jakarta Selatan), Educandum : Jurnal Ilmiah Pendidikan, 6(2).

Islamy, Athoillah. (2021). Landasan Filosofis dan Corak Pendekatan Abdurrahman Wahid Tentang Implementasi Hukum Islam di Indonesia, Jurnal Al-Adalah : Jurnal Hukum dan Politik Islam, 6(1).

Islamy, Athoillah. (2019). Dialectic Motivation, Behavior And Spiritual Peak Experience In The Perspective Of Islamic Psychology. Alfuad: Jurnal Sosial Keagamaan, 3(2).

Islamy, Athoillah. (2021). Pemikiran Hukum Islam Nurcholish Madjid. Disertasi, Pascasarjana Universitas Islam Negeri Walisongo Semarang.

Islamy, Athoillah. (2020). Aktualisasi Nilai-nilai Profetik dalam Pendidikan Keluarga di Tengah Pandemi Covid-19, Mawa'izh: Jurnal Dakwah dan Pengembangan Sosial Kemanusiaan, 11(2).

Islamy, Athoillah. (2020). Paradigma Sosial Profetik dalam Kode Etik Politik di Indonesia, Asy Syar'iyyah: Jurnal Ilmu Syari'ah dan Perbankan Islam, 5(2). 
Istiani, Nurul, Athoillah Islamy. (2020). Efektifitas Pendidikan Karakter melalui Metode Storytelling bagi Siswa Tingkat Menengah Atas(Studi Implementasi di SMK Negeri 3 Pekalongan), Edugama: Jurnal Kependidikan dan Sosial Keagamaan, 6(2).

Julianto, Very, Pipih Muhopilah. (2015). Hubungan Puasa dengan Tingkat Regulasi Kemarahan, Psympathic, Jurnal Ilmiah Psikologi, 2(1).

Maskur (2012). Ilmu Sosial Profetik Kuntowijoyo (Telaah atas Relasi Humanisasi, Liberasi, dan Transendensi). Tesis, Pascasarjana Universitas Islam Negeri Alauddin Makassar.

Mufaizin. (2018). Kearifan Syariat dan Hikmah dalam Puasa, Al-Insyiroh, 2(2).

Mukmin, Taufik. (2017). Nilai-Nilai Pendidikan dalam Ibadah Puasa, el-Ghiroh, 12(1).

Muthohar, Sofa. (2013). Antisipasi Degradasi Moral di Era Global, Nadwa : Jurnal Pendidikan Islam, 7(2).

Muhopilah, Pipih, Witrin Gamayanti, Elisa Kurniadewi. (2018). Hubungan Kualitas Puasa dan Kebahagiaan Santri Pondok Pesantren Al-Ihsan, Jurnal Psikologi Islam dan Budaya, 1(1).

Muttaqin, Husnul. (2015). Menuju Sosiologi Profetik, Sosiologi Reflektif, 10(1).

Nafis, Cholil. (2015). Menyingkap Tabir Puasa Ramadhan. Jakarta: Mitra Abadi Press.

Nurjannah. (2014). Lima Pilar Rukun Islam Sebagai Pembentuk Kepribadian Muslim, Jurnal Hisbah, 11(1).

Parrot, Justin. (2009). Islam, Iman, Ihsan: Climbing The Spiritual Mountain. Texas: Yaqeen Institut For Research.

Saryono. (2016). Konsep Fitrah dalam Perspektif Islam, Medina-Te, Jurnal Studi Islam, $14(2)$.

Shodiq. (2014). Pengukuran Keimanan: Perspektif Psikologi, Nadwa: Jurnal Pendidikan Islam, 8(1).

Suradarma, Ida Bagus. (2018) Revitalisasi Nilai-Nilai Moral Keagamaan di Era Globalisasi Melalui Pendidikan Agama, Dhaemasmrti, 9(2).

Syeikh, Abdul Karim. (2018). Rekonstruksi Makna Dan Metode Penerapan Amar Ma'ruf Nahi Munkar Berdasarkan Al-Qur'an, Al-Idarah: Jurnal Manajemen dan Administrasi Islam, 2(2).

Umiarso, Makhful. (2018). Puasa dan Pendidikan Agama Islam dalam Membangun Manusia Penaka "Tuhan": Tinjauan Kritis Terhadap Sisi Epistemologik dan Aksiologik (Pembelajaran)Pendidikan Agama Islam, Nadwa : Jurnal Pendidikan Islam, 12(1).

Wahid, Ramli Abdul. (2010). Fikih Ramadhan. Medan: Perdana Publishing.

Wulansari, Putri, Nurul Khotimah. (2019). Membumikan Ilmu Sosial Profetik: Reaktualisasi Gagasan Profetik Kuntowijoyo dalam Tradisi Keilmuwan di Indonesia, Jurnal Pendidikan Agama Islam Universitas Wahid Hasyim, Progress, 7(2).

Zaman Nazim Ali. (2012). Towards an Authentic Islamic Development Model: Incorporating the Roles of Trust and Leadership in the Islam, Iman, Ihsan Paradigm. Dissertation, Submitted in Fulfilment of the Requirements for the Degree of Doctor of Philosophy at Durham University.

ZTF, Perdana Boy. (2011). Prophetic Social Sciences: Toward an Islamic-based Transformative Social Sciences. Indonesian Journal of Islam and Muslim Societies, 1(1). 
Wawasan:

Jurnal Kediklatan Balai Diklat Keagamaan Jakarta

PISSN: 2548-9232; ${ }_{\mathrm{E}}$ ISSN: 2775-3573

Volume 2 Nomor 1 Tahun 2021: 1-15

https://islam.nu.or.id/post/read/105594/khutbah-jumat-enam-adab-berpuasamenurut-imam-al-ghazali

https://islam.nu.or.id/post/read/128710/zakat-fitrah-sebagai-penyempurna-puasadan-penyelamat-jiwa 